\title{
ТЕКСТУРНЫЕ ОСОБЕННОСТИ РУД СВИНЦОВО-ЦИНКОВОГО РУДОПРОЯВЛЕНИЯ В ЭСТОНСКОЙ ССР
}

Полиметаллические рудопроявления в Эстонской ССР распространены по всему стратиграфическому разрезу - от кристаллического фундамента до среднего девона включительно. Первые сведения о рудопроявлении в Центральной Эстонии, у Выхма, были опубликованы Вансовичем и Лемоном (1828). Исследованиями, проведенными Управлением геологии СМ Эстонской ССР, установлены следующне новые районы нахождения рудопроявления: Ульясте, Вийвиконна и Сиргала (см. рисунок). В структурно-тектоническом отношении полиметаллические рудопроявления относятся к зонам тектонического нарушения (Пальмре, 1960, 1966; Вахер и др., 1964).

Полиметаллическое рудопроявление в районе Ульясте изучено Р. Вахером, В. Пуура, Т. Кууспалу, Э. Эрисалу (1964). Рудовмещающими в этом районе являются докембрийские кристаллические породы, отнесенные названными авторами к нижнему протерозою. Верхняя часть этого комплекса представлена древней корой выветривания. По минералогическому составу в разрезе Ульясте выделяются кварциты, черные гнейсы (постоянными компонентами черных гнейсов являются графит, пирит и пироксены), мигматиты, граниты, форстеритовые и диопсидовые мраморы и пироксеновые породы. В докембрийских кристаллических породах Р. Вахер, В. Пуура и др. (1964) выделяют два разновозрастных парагенезиса сульфидных минералов. К более древнему из них относятся пирротин и пирит с незначительной примесью халькопирита, распространенные в графитсодержащих породах. Второй по возрасту парагенезис представлен галенитом, сфалеритом, пиритом и очень редко халькопиритом.

Р. Вахер, В. Пуура и др. (1964) отмечают, что пирротин и пирит встречаются в виде вкраплений или образуют удлиненные агрегаты. Галенит-сфалерит-пиритовая минерализация приурочена к карбонатным породам и гнейсам, причем сульфидные минералы этого парагенезиса заполняют различные пустоты и трещины.

Материал для изучения текстур и структур рудопроявления в породах кристаллического фундамента был получен автором из Управления геологии СМ Эстонской С.С. При изучении текстур сульфидных руд в породах кристаллического фундамента автор выделил друзовые, вкрапленные и прожилковые текстуры (габл. I, фиг. 2, 4). Из структур руд в докембрийских кристаллических породах можно выделить главным образом гипидиоморфнозернистую структуру (табл. 1, фиг. 1), в то время как скелетообразные структуры встречаются сравнительно редко. Все названные генетические группы текстур и структур широко распространены в гидротермальных рудных месторождениях (Бетехтин, Генкин и др., 1964). Гриведенные выше данные позволяют предполагать, что полиметаллическое рудопроявление в кристаллическом фундаменте Эстонской ССР носнт гидротермальный (телетермальный) характер.

На участках Вийвиконна и Сиргала рудопроявление установлено лишь в ордовикских отложениях, причем рудовмещающими породами являются доломитизированные известняки. В Центральной Эстонии, на участке Выхма, рудопроявление установлено 


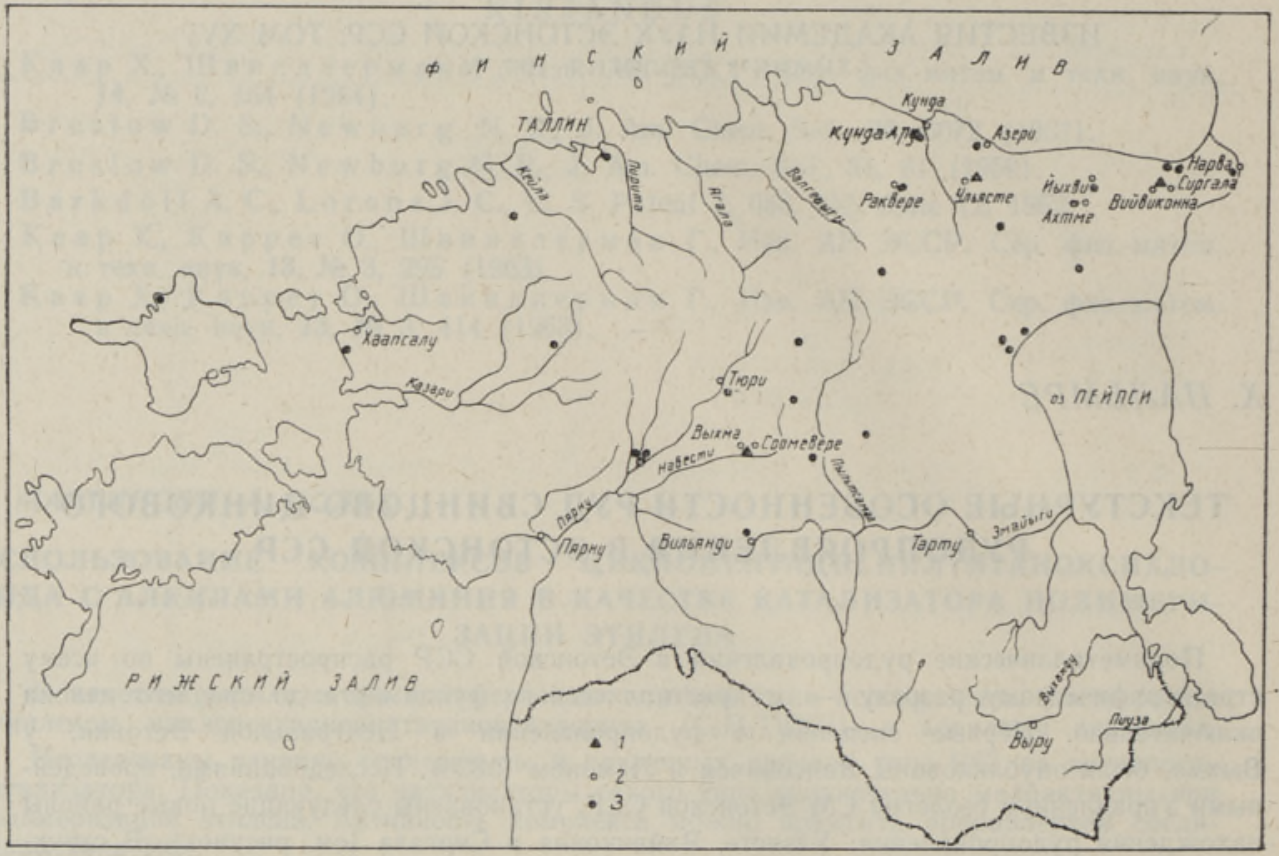

Схематическая карта распространения наиболее известных рудопроявлений: 1 - наиболее известные рудопроявления; 2 - населенные пункты; 3 - одиночные находки галенита и сфалерита.

главным образом в нижнесилурийских доломитах и доломитизированных известняках н. частично в среднедевонских домеритах.

Наличие тектонического контроля оруденения, связь рудопроявления с зонами тектонической трещиноватости, проявление доломитизации, а иногда слабого скварцевания в околорудных породах послужили основанием для отнесения рудопроявления на названных участках к телетермально-гидротермальному типу (Вахер и др., 1964). Характерной ссобенностью геологического строения районов этого типа рудопроявления является отсутствие изверженных пород. что позволило некоторым исследователям поставить под сомнение гидротермальное лроисхожденне руд данного типа и отстаивать гипотезу об их первично осадочном образовании (Газизов, 1962). В связи с изложенным особый интерес представляло изучение текстур и структур рудопроявления, образовавшихся среди карбонатных пород, в кавернах, трещинах и брекчированных породах ордовика и силура вышеназванных местонахождений.

Как показывают литологические исследования нижнесилурийских карбонатных пород адавереского горизонта, * первоначально образовались известняки, которые позднее подверглись доломитизации н, по всей вероятности, в ходе доломитизации появились отдельные поры и каверны.

Необходимо, кроме того, отметить, что в образовании каверн и перекристаллизации первичного карбонатного материала большое значение имели вымершие строматопороидеи, кораллы и другие окаменелости, которые при доломитизации частично разлагались. В том месте, где они находились, оставались каверны, а карбонатный материал этих окаме-

* H. P a $1 \mathrm{mr}$ e, Adavere lademe üldine litoloogiline iseloomustus. Tallinn, 1960. Рукопись в фондах Института геологии Академин наук Эстонской ССР. 
нелостей подвергался переотложению. В результате этого процесса образовалась сильнопористая и кавернозная порода, которая является подходящей средой для отложения рудного и нерудного материала. В течение этого процесса, по всей вероятности, возникли также каверны, стенки которых позже покрылись кристаллами белого доломита. Помимо того, образование тектонически нарушенных зон, секущих пористые и кавернозные породы, обусловило возникновение новых пор, каверн и трещин, в которые позднее просочились рудоносные растворы.

Процесс образования каверн и перекристаллизации карбонатного материала пород можно хорошо проследить на брекчированных доломитах, в которых сначала появляются маленькие светлые пятна, указывающие на начало разложения первоначальной породы, а затем образуются поры и пустоты, постепенно увеличивающиеся в размерах (табл. II, фиг. 2). Одновременно с этим, по-видимому, происходнли также вынос карбонатного материала и его переотложение. В результате такого процесса появляются каверны разной величины. Позднее в этих кавернах из рудоносных растворов осаждались прозрачные кристаллы доломита и минералы - пирит, марказит, галенит, сфалерит, халькопирит и арсенопирит.

Микроскопическое исследование разрезов каверны показало, что на стенках каверн после их образования отлагался сульфидный и карбонатный материал. Так, во вмещающей породе в стенке каверны были вкраплены главным образом мелкие кристаллы пирита и сфалерита (табл. I, фиг. 3). Их количество среди кристаллов доломита уменьшается по мере удаления от стенки каверны. Каверны иногда выстланы мельчайшими кристалликами сульфидных минералов, образующими тонкую пленку, на которую наросли белые крупные кристаллы доломита слоем толщиной до 0,5 cм, а иногда и больше. Среди белых кристаллов доломита можно встретить кристаллы пирита и сфалерита (табл. II, фиг. 3). Впоследствии на слой белого доломита наросли сульфидные минералы, в первую очередь пирит, а на последнем отложились галенит и сфалерит (табл. I, фиг. 5).

Такое последовательное нарастание минеральных агрегатов в кавернах характерно для Центральной и Северо-Восточной Эстонии. Можно полагать, что эти последовательно отложившиеся минералы образуют парагенетическую минеральную ассоциацию. Такая же минеральная ассоциация встречается в кристаллическом фундаменте в Ульясте. Возможно, что названные минеральные ассоциации образовались из одного и того же рудного раствора, так как у них концентрация микроэлементов в сульфидных минералах (Пальмре, Иоханнес, 1964) была почти одинаковая. Можно полагать, что эта минеральная ассоциация образовалась в течение одной стадии рудоотложения.

В карбонатных породах часто встречаются каверны, где наблюдаются крупные агрегаты пирита, наросшие на крупнокристаллический доломит (табл. II, фиг. 1). Кроме пирита, в таких кавернах встречаются кристаллы марказита, халькопирита, галенита, арсенопирита и прозрачные ромбоэдрические кристаллы доломита. Необходимо также отметить, что в некоторых кавернах поверхность галенита корродирована (табл. III, фиг. 3).

Исследование текстур брекчированных доломитов в Центральной и Северо-Восточной Эстонии показывает (табл. III, фиг. 1, 2), что обломки доломитов сцементированы карбонатным материалом (кальцитом и доломитом) и очень редко баритом. Обломки часто покрыты тонким слоем сульфидных минералов (табл. III, фиг. 2). Строение таких кокар- 
довых текстур показывает, что при их образовании поступали растворы, содержащие незначительное количество рудного вещества.

В зонах тектонической трещиноватости местами встречаются также прожилковые текстуры. Рудные прожилки в общем маломощные. Ширина наиболее крупных из них колеблется в основном от 1 до 2 cм. В окрестностях Кохтла-Ярве, в шахте № 2, в одном случае вскрыта жила мощностью 7 см (Газизов, 1958), целиком сложенная галенитом, а в районе Выхма известен прожилок сплошного галенита мощностью до 2 см. Обычно ширина прожилков не превышает нескольких миллиметров. В одних случаях они состоят сплошь из пирита или галенита, в других - из галенита, сфалерита, пирита, марказита, халькопирита и из нерудных минералов - кальцита и доломита. При детальном изучении установлено их симмелричное строение, хорошо видное на табл. IV, фиг. 3.

\section{ТАБЛИЦА I}

Фиг. 1. Гипидиоморфнозернистая структура. Пирротин (светло-серый), пирит (белый), нерудные минералы (черные). Полированный шлиф, $\ 2,5$. Нижний протерозой, Ульясте. Фиг. 2. Вк̌рапленность и прожнлки сульфидов (пирротина и пирита) в гнейсах. Полированный шлиф, $Х 2,5$. Ннжний протерозой, Ульясте.

Фиг. 3. Крупнозернистый, пористый доломит (пестро-серый) с узкой каймой белых кристаллов доломита. Среди крупнозернистого доломита видны черные пятна (пирит). На белых кристаллах доломита - сфалерит (черный). Полированный шлиф, $\underset{X}{ } 3$. Нижний силур, р. Навести.

Фиг. 4. Тонкие прожилки галенита и пирита (белый) в гнейсах. Полированный шлиф, $\times 2,5$. Нижний протерозой, Ульясте.

Фиг. 5. Часть стенки каверны. Внизу боковая порода (пестрая) - крупнозернистый доломит с зачатками перекристаллнзацин доломита (белые пятна). На крупнозернистый доломит нарос белый доломит (белая кайма). На крнсталлах доломита - агрегат гирита (светло-серая полоса), а на нем - сфалерит и галенит (черные). Полированный шлиф, $\times 5$. Нижннй силур, р. Навести.

Фиг. 6. Агрегаты пирита (светло-серые), наросшие на крупнокристаллический доломит (темно-серый). Полированный шлиф, $× 5$. Нижний силур, р. Навести.

\section{ТАБЛИЦА II}

Фиг. 1. Крупные агрегаты пирита (светло-серыє) наросли на крупнокристаллический доломит (темно-серый). Полированный шлиф, $\times 5$. Нижний силур, р. Навести.

Фиг. 2. Угловатые обломки доломита (темно-серые), цемент - карбонатная масса (светло-серый доломит). В центре обломков появляются сначала маленькие поры, которыепостепенно увеличиваются. В результате разложения и выноса карбонагного матернала образуются каверны. В центре - большая каверна. Полированный штуф, нат. вел. Нижний силур, р. Навесги.

Фиг, 3. На стенке каверны в крупнокристаллическом доломите видна кайма белого доломита. В последнем - крупные кристаллы сфалерита (черные пятна). Внизу мелкозернистый серый доломит с полосами темно-серого доломита. Полированный шлиф, $X 4$. Средний ордовик, Соомевере.

\section{ТАБЛИЦА III}

Фиг. 1. Обломки доломита (темно-серые) с кальцитовым цементом (белый) и галенитом (серый). Полированный шлиф, Х 3 . Средний ордовик, карьер «Вийвиконна».

Фиг. 2. Қокардовая текстура. Обломки грубозернистого доломита (черные), кайма пирита (темно-серая), а сверху - кайма белого доломита, выше которой находится агрегат сфалерита (серый). Полированный шлиф, Х 3 . Нижний силур, р. Навести.

Фиг. 3. Крупные кристаллы галенита (светло-серые, пятнистые) на крупных кристаллах пирита (темно-серые). Внизу - фестончатая полоса белого крупнокристаллического доломита. Поверхность кристаллов галенита сильно корродирована. Штуф, $\mathbf{X} 2$. Нижний силур, р. Навести. 

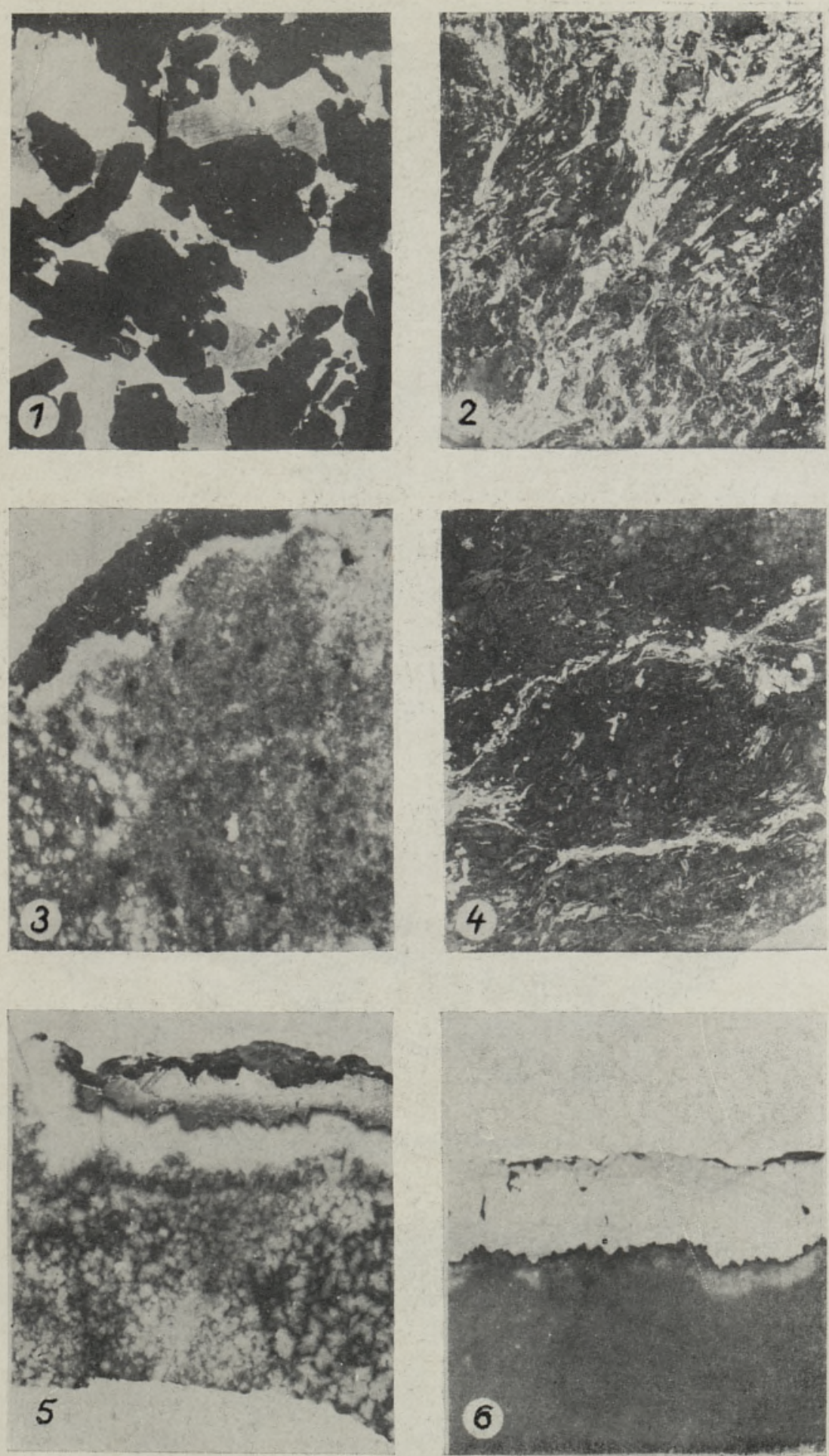


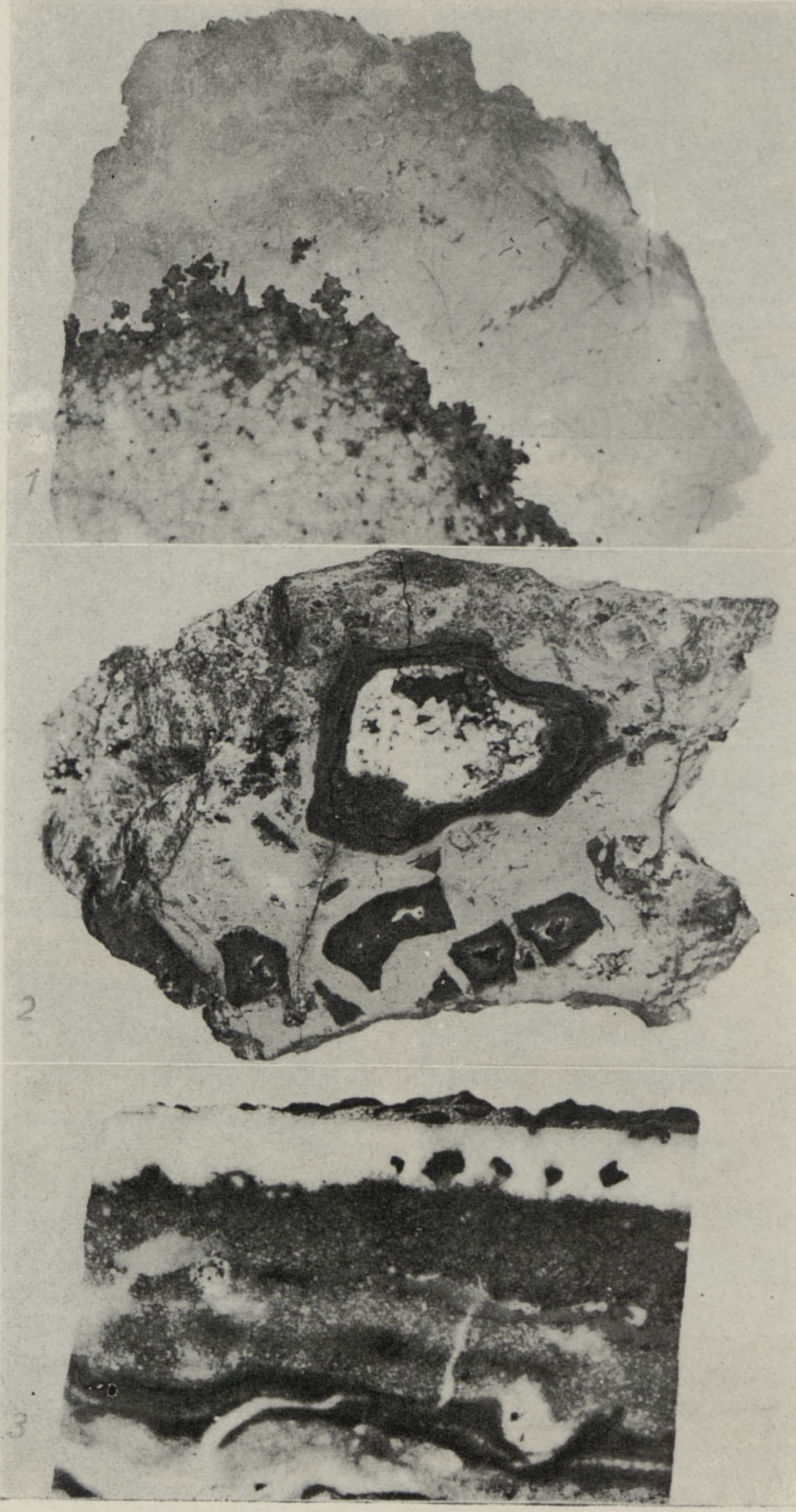



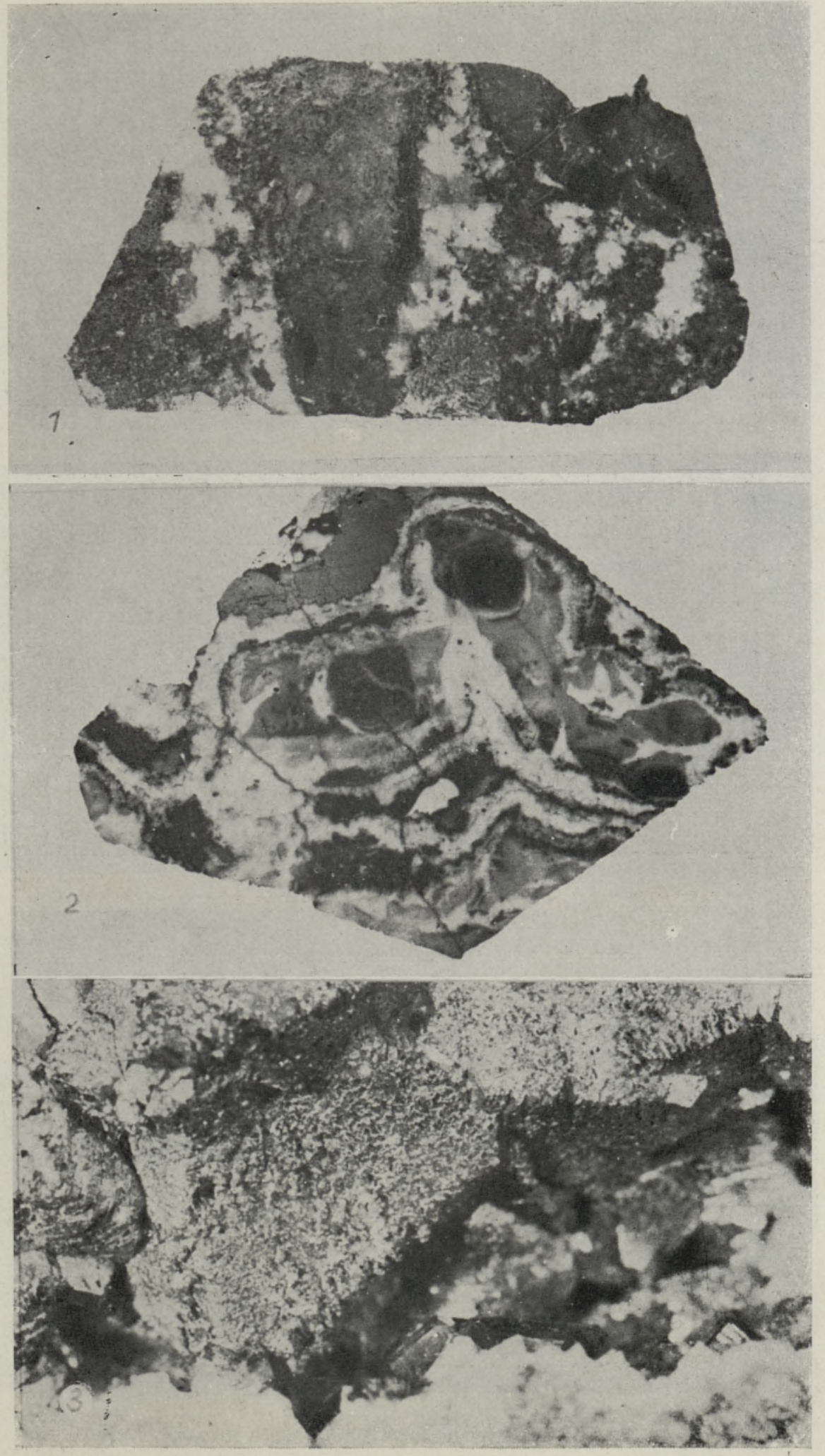

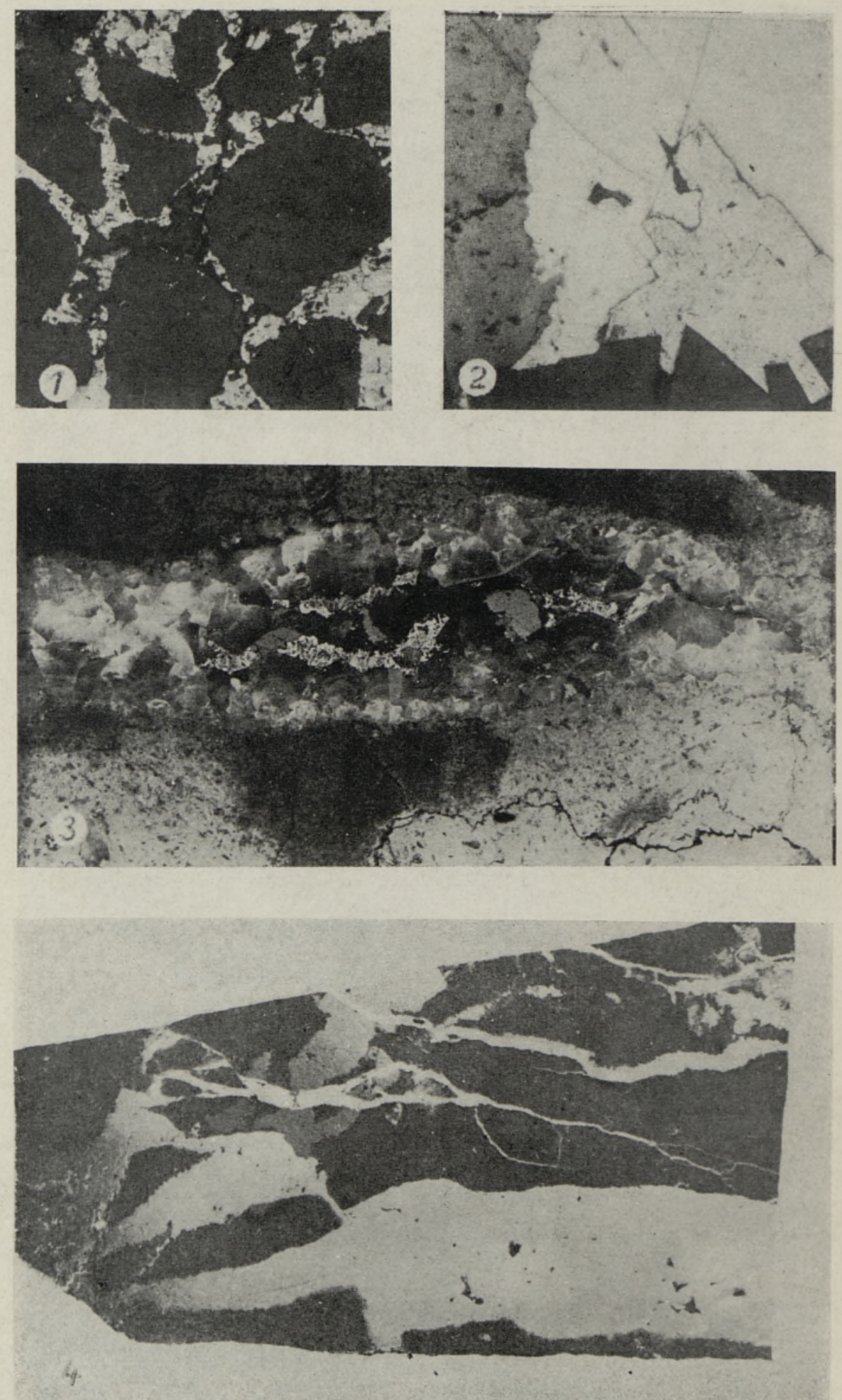

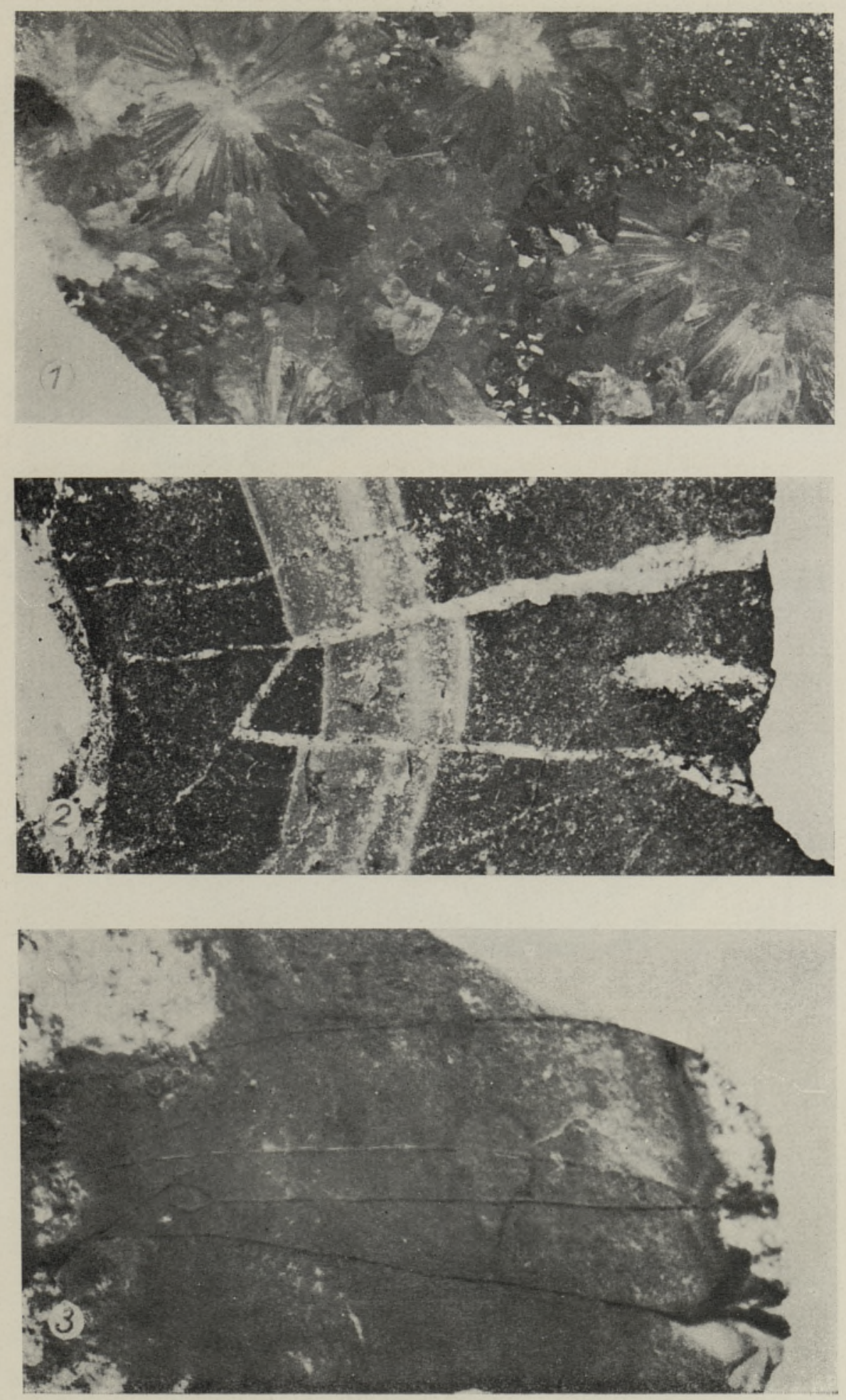


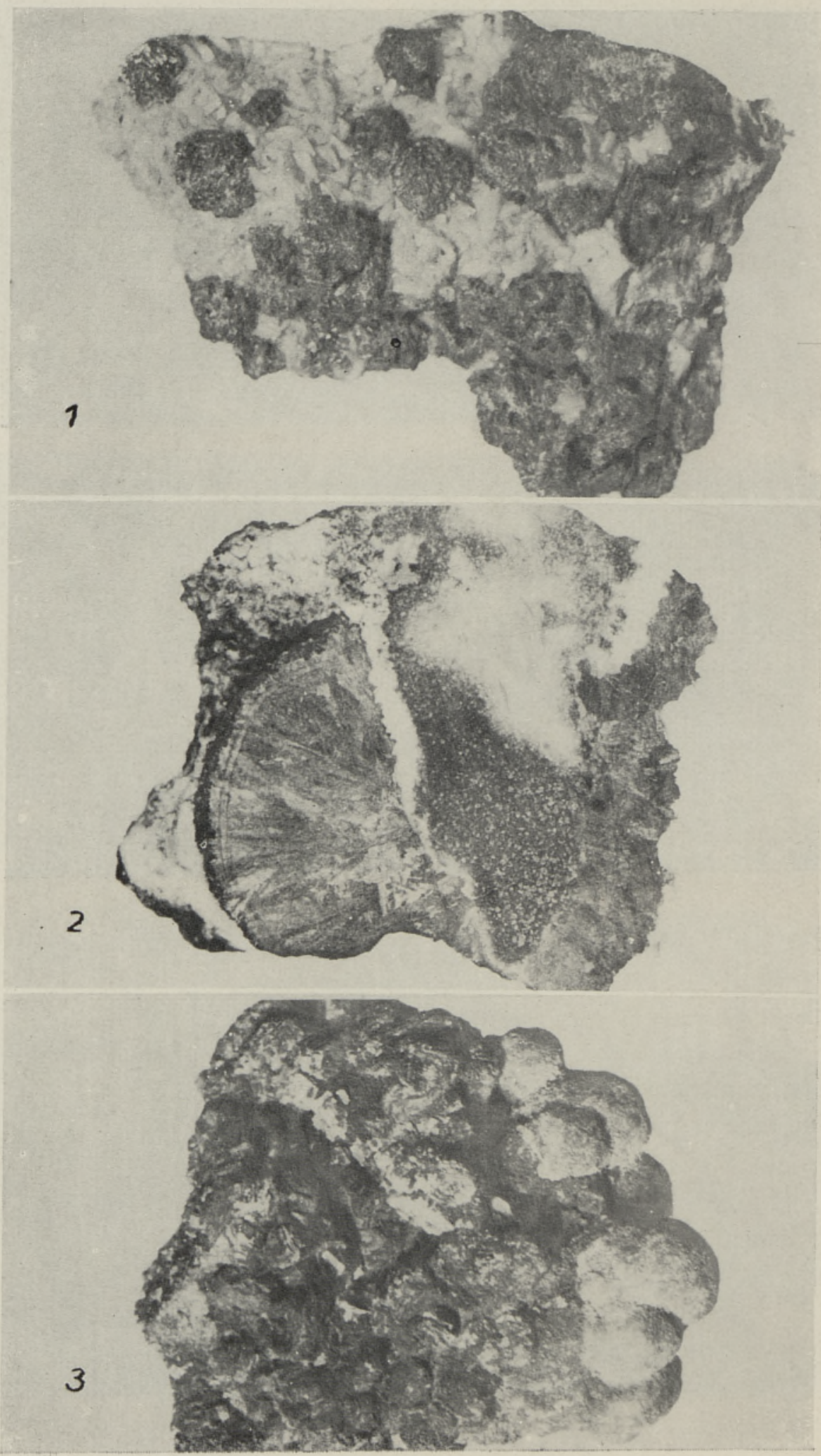


Изучение симметрично-полосчатых прожилков в карьере Кунда-Ару показывает, что на стенках трещин сначала отложились полоски микрокристаллического пирита, затем мощная полоса кальцита, центральные же части прожилков сложены сфалеритом, галенитом и, по всей вероятности, баритом. На такую последовательность отложения минералов в трещинах Северной Эстонии обратил внимание также Э. Mёльс (Möls, 1961). В другом случае установлено, что на стенках трешин из циркулирующих растворов отлагались пирит, марказит, халькопирит, галенит, сфалерит и кальцит, которые покрывают стенки крустификационным слоем толщиной $1-3$ мм (табл. $\mathrm{V}$, фиг. 1). Такие рудные прожилки пересекают брекчированные доломиты в Центральной и Северо-Восточной Эстонии (табл. V, фиг. 2, 3).

Исследования в окрестностях Вийвиконна и Сиргала показывают, что рудоносные и безрудные растворы проникали также в жилы песчаника. Из этих растворов выпадали сульфидные минералы, а также карбонаты, которые распространились по всей породе и сцементировали зерна песчаника. Просочившиеся растворы, видимо, были щелочными, о чем свидетельствует коррозия кварцевых зерен песчаника (табл. IV, фиг. 1). Рудные прожилки, пересекающие жилы песчаника, содержат галенит, пирит, марказит, сфалерит, кальцит и доломит (табл. IV, фиг. 2) и образовались позднее жил песчаника. Исследование заполненных песчаником трещин-жил в Северо-Восточной Эстонии показало, что

\section{ТАБЛИЦА IV}

Фиг. 1. Цементная структура. Зерна кварца (черные) сцементированы пиритом (светлосерый) и частично корродированы. Полированный шлиф, Х 20. Средний ордовик, шахта № 8 в Н̆ыхви.

Фиг. 2. Деталь рудного прожилка. Кристаллы кальцита (черные), сфалерита (темносерые слева), пирита (серые). и галенита (светло-серые). Полированный шлиф, $\times 210$. Средний ордовик, Сиргала.

Фиг. 3. Симметричное строение рудного прожилка. На стенках трещины - кальцит с мелкими кристаллами пирита (светло-серая полоса). На кальците симметрично расположен пирит (светло-серый) и в центре - калыцит (черный) и сфалерит. Полированный шлиф, $Х 2$. Нижний ордовик, Кунда-Ару.

Фиг. 4. Жильная текстура. Агрегат галенита ранней рудной стадии (серый), пересечен прожилком пирита поздней стадии (белый). Полированный шлиф, Х 3 . Средний ордовик, Вийвиконна.

\section{ТАБЛИЦА $V$}

Фиг. 1. Крустификационная текстура. На стенках трещины - мелкие кристаллы пирита, марказита, галенита (светлые пятна) и барит (радиально-лучистый). Штуф, $\times 5$. Средний ордовик, Сиргала.

Фиг. 2. Микросброс в брекчированном доломите. Обломок прорезан кальцитовыми прожилками. В тонких прожилках кальцита видны темные пятна галенита (черные). Штуф, $\times 6$. Средний ордовик, Вийвиконна.

Фиг. 3. Трещнноватая конкреция халцедона. Трещины заполнены сульфидными минералами. С поверхности халцедон подвергся разложению. Штуф, $X 2$. Нижний силур, p. Навести.

\section{ТАБЛИЦА VI}

Фиг. 1. Сферические образования сфалерита (темно-серые) на белом доломите с изогнутыми гранями кристаллов (светло-серые). Нат. вел. Нижн. силур, р. Навести.

Фиг. 2. Сферическое образование сфалерита (радиально-лучистый агрегат) на кристаллах белого доломита. Полированный шлиф, $\times 3$. Нижний силур, p. Навести.

Фиг. 3. Натечно-колломорфный агрегат пирита. Отдельные агрегаты с поверхности сравнительно гладкие и не имеют признаков перекристаллизации. Нат. вел. Нижний силур, р. Навести. 
рудные прожилки в них пересекаются между собой. Микроскопическим изучением установлено, что прожилки пирита, марказита прорезают агрегаты галенита и сфалерита (табл. IV, фиг. 4). Рудные прожилки, пересекающие агрегаты галенита, вероятно, образовались из рудных растворов, проникших в породу во время тектонических подвижек. Все эти признаки, указывающие на возрастные различия отложенных минеральных агрегатов, представляют интерес, так как позволяют проследить стадиальный характер процесса рудопроявления.

Исследование полиметаллического рудопроявления показывает, что в Эстонской ССР встречаются следующие текстуры рудообразования: вкрапленная, симметрично-полосатая, жильная, крустификационная, кокардовая, натечно-колломорфная и друзовая.

Среди кристаллических пород нижнего протерозоя распространяются в основном вкрапленные, жильные и друзовые текстуры, причем нужно отметить, что друзовые образования здесь небольшие.

В тектонически трещиноватых зонах Северо-Восточной и Центральной Эстонии в карбонатных породах встречаются в основном все названные выше текстуры, но они не имеют одинакового распространения. Среди карбонатных пород среднего девона Центральной Эстонии пока установлено только незначительное рудопроявление в виде очень небольших друз и прожилков.

В генетическом отношении более сложными являются кокардовые текстуры. Последние в местонахождениях полиметаллического рудопроявления возникали, вероятно, путем обрастания обломков брекчии выделившимися из рудообразующих растворов жильными и рудными минералами. В полостях вмещающей породы встречаются различные почковидные, гроздевидные, сферические и полусферические рудные образования (табл. VI, фиг. 1-3). Морфологические особенности этих рудных образований свидетельствуют, по-видимому, о том, что они возникли из коллоидных растворов. Образование сферических поверхностей представляет собой характерное свойство гелей и обусловлено явлениями поверхностного натяжения жидких или полужидких масс, вызванными стремлением вещества принять шарообразную форму с наименьшей поверхностью.

На табл. VI, фиг. 1, 2 почковидный агрегат сфалерита с поверхности покрыт гранями кристаллов и в разрезе имеет радиально-лучистое строение. В верхней части этот агрегат имеет концентрически-зональное строение (черные зоны - тонкодисперсный или скрытокристаллический сфалерит; светло-серые зоны - более грубозернистый сфалерит радиально-лучистого строения).

Обычно перекристаллизация коллоидных осадков в гидротермальных месторождениях протекает настолько интенсивно, что на месте гелей образуются зернистые агрегаты. В окрестностях Выхма и Сиргала эти рудные образования, видимо, не подверглись еще сколько-нибудь значительной перекристаллизации и поэтому у сферических образований ясно выступает радиально-лучистое строение (табл. VI, фиг. 2).

Исследование минеральных агрегатов показывает, что при дальнейшей кристаллизации минералов из коллоидных растворов, заключенных в образовавшихся полостях и трещинах, концентрация их компонентов постепенно уменьшалась, в связи с чем образовались более крупные кристаллические минеральные агрегаты. Под конец, когда растворы стали слабоконцентрированными, из них выпали хорошо ограненные и относительно крупные кристаллы (2 cM), которые наросли на стенки пустот породы. 
Согласно классификации текстур руд, созданной А. Бетехтиным (1937), С. Вахромеевым (1956) и др., вышеназванные текстуры рудопроявления характерны для гидротермальных рудных месторождений, и поэтому можно полагать, что полиметаллическое рудопроявление в Эстонии имеет также гидротермальный характер.

По данным микроскопических исследований, в Эстонии в зонах тектонической трещиноватости из рудных минералов встречаются пирит, марказит, галенит и сфалерит. Кроме того, присутствуют еще как второстепенные минералы арсенопирит, халькопирит, барит, кварц, кальцит, доломит, целестин, сидерит и анкерит. Последние три минерала встречены автором только в некоторых буровых скважинах Центральной Эстонии.

При изучении минералогического состава, а также текстурных особенностей микроскопическим методом можно выделить следующие минеральные парагенетические ассоциации, отвечающие последовательным стадиям минералообразования:

1) пирротин-пиритовую, в докембрийских кристаллических породах;

2) пирит-галенит-сфалеритовую, в докембрийских, ордовикских и силурийских породах;

3) пирит-марказит-галенит-сфалерит-кальцит-доломитовую, в ордовикских и силурийских породах.

Наиболее ранняя, пирротин-пиритовая минеральная ассоциация содержит незначительную примесь халькопирита и, возможно, пентландита. Эта минеральная ассоциация распространяется в докембрийских породах в Ульясте.

Вторая ассоциация - пирит-галенит-сфалеритовая, также встречающаяся в докембрийских породах, очень редко содержит халькопирит. В Центральной и Северо-Восточной Эстонии среди карбонатных пород налеозоя пирит-галенит-сфалеритовая ассоциация являегся наиболее ранней и характеризуется переменным количественным соотношением рудных минералов, причем следует отметить, что халькопирит в этой ассоциации отсутствует. В Северо-Восточной Эстонии, в Вийвиконна и Сиргала, в этой минеральной ассоциации между обломками доломита часто встречаются кальцит, доломит и барит, образовавшиеся в более позднее время. Минеральная ассоциация, сложенная пиритом, марказитом, галенитом, сфалеритом, халькопиритом, кальцитом и доломитом, относится к третьей стадии гидротермальных образований. Она распространена среди палеозойских карбонатных пород и образует крустификационные текстуры на стенках трещин. Халькопирит, арсенопирит и барит присутствуют здесь в подчиненных или резко подчнненных количествах. Мелкие кристаллы развиты также в кавернах, где они покрывают крупные минеральные агрегаты пирита, галенита и сфалерита, которые образовались уже раньше среди карбонатных пород ордовика и силура. Кроме того, эта минеральная ассоциация развита в кавернах, где слой кристаллов белого доломита отсутствует. В качестве второстепенных или малораспространенных минералов эти агрегаты содержат доломит и кальцит. Пирит-марказитовая ассоциация распространена главным образом в виде прожияок в брекчированных доломитах Северо-Восточной и Центральной Эстонии, где они пересекают минеральные агрегаты ранней стадии рудоотложения.

На основе изложенного выше можно полагать, что процесс рудоотложения в зонах тектонической трещиноватости в Северо-Восточной и Центральной Эстонии протекал, по всей вероятности, в три стадии (см. таблицу). 


\begin{tabular}{|c|c|c|c|}
\hline \multirow{2}{*}{$\begin{array}{c}\text { Стадия } \\
\text { минераліо- } \\
\text { образова- } \\
\text { ния }\end{array}$} & \multirow[b]{2}{*}{$\begin{array}{c}\text { Минеральные } \\
\text { ассоциации }\end{array}$} & \multicolumn{2}{|c|}{ Второстепенные минералы } \\
\hline & & $\begin{array}{c}\text { сульфиды и } \\
\text { сульфаты }\end{array}$ & $\begin{array}{c}\text { карбонаты и } \\
\text { окнслы }\end{array}$ \\
\hline 1 & $\begin{array}{l}\text { Пирротин- } \\
\text { пиритовая }\end{array}$ & $\begin{array}{l}\text { Халькопирит } \\
\text { Пентландит? }\end{array}$ & $\begin{array}{l}\text { Кварц } \\
\text { Кальцит }\end{array}$ \\
\hline II & $\begin{array}{l}\text { Пирит- } \\
\text { галенит- } \\
\text { сфалеритовая }\end{array}$ & Барит & $\begin{array}{l}\text { Кальщит } \\
\text { Доломит }\end{array}$ \\
\hline III & $\begin{array}{l}\text { Пирит- } \\
\text { марказит- } \\
\text { галенит- } \\
\text { сфалерит- } \\
\text { кальцит- } \\
\text { доломитовая }\end{array}$ & $\begin{array}{l}\text { Халькопирит } \\
\text { Арсенопирит } \\
\text { Барит }\end{array}$ & $\begin{array}{l}\text { Кальцит } \\
\text { Доломит }\end{array}$ \\
\hline
\end{tabular}

Изучение текстурных особенностей рудных образований рудопроявления в тектонически нарушенных зонах Северо-Восточной и Центральной Эстонии позволяет сделать некоторые выводы о процессе их формирования.

1. Рудные минералы осаждались из рудоносных растворов в пустотах гнейсов, мраморов докембрия и карбонатных пород ордовикского и силурийского возраста. Об этом свидетельствуют повсеместно встречающиеся в полостях растворения друзовые текстуры сульфидных минералов, а также брекчневидные и кокардовые текстуры. Последовательность нарастания друг на друга белого крупнозернистого доломита. пирита, галенита, сфалерита и чередование тонких слоев пирита и доломита указывает на то, что заполнение пустот минералами происходило из растворов, состав которых, очевидно, менялся во времени.

Почковидные поверхности агрегатов пирита и сфалерита показывают, что они возникли из коллоидных растворов, а наличие трещин усыхания в агрегатах позволяет предполагать, что эти минералы претерпели перекристаллизацию.

2. В результате последующих тектонических подвижек ранее образовавшиеся брекчии и связанные с ними рудные скопления пересечены жилами и прожилками новой стадии минерализации. В последних присутствуют пирит, марказит, халькопирит, галенит и сфалерит. В открытых трещинах эти минералы образуют крустификационные текстуры.

Отмеченные текстурные особенности руд позволяют высказать мнение, что руды имеют эпигенетический характер и образовались из гипогенных рудоносных растворов, которые циркулировали в кристаллическом фундаменте и в осадочном чехле.

Исследования показали, что процесс рудоотложения протекал в три стадии. Тектонические подвижки предшествовали каждому новому поступлению рудоносных растворов нли сопровождали его, вследствие чего новые минеральные ассоциации покрывают более ранние. 


\section{Л И Т Е Р А У Р А}

Бетехтин А. Г., 1937. Классифнкация текстур и структур руд, М.

Бетехтин А. Г., Генкин А. Д., Филнмонова А. А., Шадлун Т. Н., 1964. Структурно-текстурные особенности эндогенных руд, $M$.

В ансович и Л мон, 1828. О разведках свинцовых прнисков, произведенных в 1803 г. в Лифляндской губернии, в Феллинском уезде, Горн, журн,, IX.

В а хромеев С. А., 1956. Руководство по минераграфни, Иркутск.

В ахер Р. М., К у успалу Т. И., Пу ура В. А., Эрисалу Э. К., 1964. О геологическом положении сульфндных рудопроявлений в районе Ульясте, Литология палеозойских отложений Эстонии, Таллин.

Г а з и з о В М. С., 1958. К вопросу о морфологии и пронсхождении глубинного карста в Прибалтийском сланцевом бассейне. Тр. Ин-та геол. АН ЭССР, II.

Г а $з$ и з о в М. С., 1962. Сульфидные минералы, связанные с карстом на Эстонском сланцевом месторождении, Специальные вопросы карстоведения, $M$.

П а льм р е Х. Г., 1960. Закономерности полиметаллического оруденения на территории Эстонской ССР, Киев.

П а льм ре Х. Г., Иоханнес Э. Я., 1964. О некоторых микроэлементах в сульфидных минералах Әстонии, Литология палеозойских отложений Эстонии, Таллин.

П альм р е X. Г., 1966. О тектоническом нарушении в районе Выхма (Центральная Эстония), Изв. АН ЭССР. Сер. физ.-матем. и техн. наук, 15, № 2.

Mö Is E. J., 1961. Eesti aluspōhja lôhede geneesist, ENSV TA Loodusuurijate Selts, Tartu.

Ннститут геологии

Академии наук Эстонской ССР
Поступила в редакцию 8/XII 1966

\section{H. PALMRE}

\section{PLII- JA TSINGIMAAGI ILMUNGI TEKSTUURILISED ISEĂRASUSED EESTI NSV-S}

Käesolevas artiklis antakse esmakordselt lühike ülevaade Eesti NSV-s polümetallilisel maagistumisel kujunenud plii- ja tsingimaagi tekstuuridest, mis on tekkinud aluskorra ja aluspōhja kivimite poorides, kavernides ja lōhedes. Esinevad hajutatud, soonelised, sümmeetriliselt vöödilised, koorikulised, tärnjad, bretšalised, druusilised ja kollomorfsed tekstuurid. Viimaste levik on vôrdlemisi laialdane, mis viitab sellele, et aluspōhja kivimeis on tsirkuleerinud kolloidsed lahused. Uldtunnustatud arvamuse alusel esinevad kồk nimetatud maagitekstuurid hüdrotermiliselt tekkinud polümetallilise maagi leiukohtades. Vōib arvata, et Eesti NSV-s esinev polümetalliline maagistumine on samuti hüdrotermaalse iseloomuga ning maagid on tekkinud hüpogeensetest maake kandvatest lahustest, mis tsirkuleerisid nii kristalses aluskorras kui ka settekivimilises kompleksis. Uurimine näitas, et maagistumine kulges kolme staadiumi vältel. Tektooniliste liikumistega kaasnenud maake kandvatest lahustest settisid pürrotiin-püriidi, püriit-galeniit-sfaleriidi, püriit-markasiit-kalkopüriit-galeniit-sfaleriidi assotsiatsioonid, kusjuures iga uus neist kattis varem settinud mineraalide assotsiatsiooni.

\section{H. PALMRE}

\section{UBER DIE TEXTUREN DER BLEI-ZINKERZEERSCHEINUNGEN IN DER ESTNISCHEN SSR}

Im vorliegenden Artikel wird erstmalig eine kurze Obersicht über die Texturen der Blei-Zinkerze gegeben, welche in den Poren, Kavernen und Spalten des Nebengesteines vorkommen.

Mittels mineralogischer Untersuchungen sind folgende Texturen aufgeklärt worden: zerstreute, gangartige, brekzienartige, drusige und Krustetexturen. Es kommen auch sphärische Texturen vor, besonders bei den Zinkblenden und Pyriten, wodurch bestätigt wird, daß sie aus kolloiden Lösungen entstanden sind.

Mittels Untersuchungen ist es auch festgestellt worden, daB die Blei-Zinkerze in der Estnischen SSR epigenetisch aus schwach konzentrierten Lösungen in drei Stadien entstanden. 